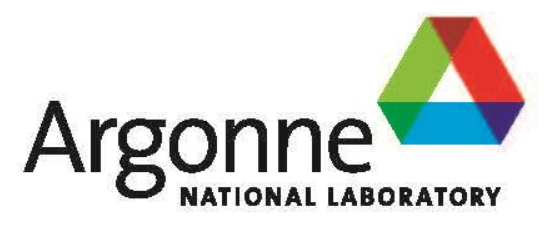

\title{
Direct Down-scale Experiments of Concentration Column Designs for SHINE Process
}

Nuclear Engineering Division 


\begin{abstract}
About Argonne National Laboratory
Argonne is a U.S. Department of Energy laboratory managed by UChicago Argonne, LLC under contract DE-AC02-06CH11357. The Laboratory's main facility is outside Chicago, at 9700 South Cass Avenue, Argonne, Illinois 60439. For information about Argonne and its pioneering science and technology programs, see www.anl.gov.
\end{abstract}

\title{
DOCUMENT AVAILABILITY
}

Online Access: U.S. Department of Energy (DOE) reports produced after 1991 and a growing number of pre-1991 documents are available free via DOE's SciTech Connect (http://www.osti.gov/scitech/).

Reports not in digital format may be purchased by the public from the National Technical Information Service (NTIS):

U.S. Department of Commerce

National Technical Information Service

5301 Shawnee Road

Alexandria, VA 22312

unw.ntis.gov

Phone: (800) 553-NTIS (6847) or (703) 605-6000

Fax: (703) 605-6900

Email: orders@ntis.gov

Reports not in digital format are available to DOE and DOE contractors from:

U.S. Department of Energy

Office of Scientific and Technical Information

P.O. Box 62

Oak Ridge, TN 37831-0062

\section{Disclaimer}

This report was prepared as an account of work sponsored by an agency of the United States Government. Neither the United States Government nor any agency thereof, nor UChicago Argonne, LLC, nor any of their employees or officers, makes any warranty, express or implied, or assumes any legal liability or responsibility for the accuracy, completeness, or usefulness of any information, apparatus, product, or process disclosed, or represents that its use would not infringe privately owned rights. Reference herein to any specific commercial product, process, or service by trade name, trademark, manufacturer, or otherwise, does not necessarily constitute or imply its endorsement, recommendation, or favoring by the United States Government or any agency thereof. The views and opinions of document authors expressed herein do not necessarily state or reflect those of the United States Government or any agency thereof, Argonne National Laboratory, or UChicago Argonne, LLC. 


\section{Direct Down-scale Experiments of Concentration Column Designs for SHINE Process}

by

Amanda J. Youker, Dominique C. Stepinski, and George F. Vandegrift

Nuclear Engineering Division, Argonne National Laboratory

May 2017 



\section{CONTENTS}

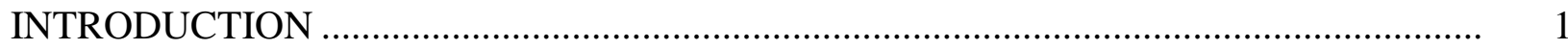

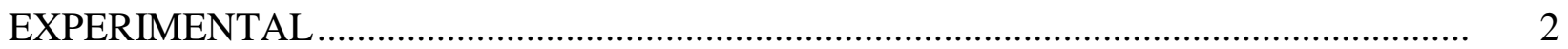

Preparation of Mo-99 Spike Solution ............................................................................. 2

AKTA Column Experiments ................................................................................... 2

Counting of Mo-99 ............................................................................................ 2

RESULTS AND DISCUSSION _.....................................................................................

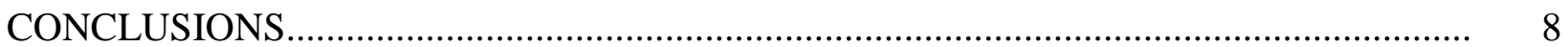

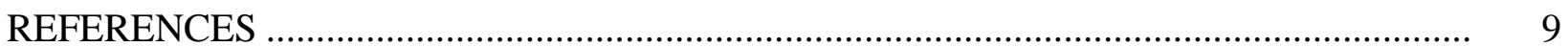

\section{FIGURES}

1 Strip curve for the down-scale column experiment performed at $50^{\circ} \mathrm{C}$ with a loading velocity of $28.2 \mathrm{~cm} / \mathrm{min}$ and a stripping velocity of $6.5 \mathrm{~cm} / \mathrm{min}$.

2 Strip curve for the down-scale column experiment performed at $50^{\circ} \mathrm{C}$ with a loading velocity of $32.9 \mathrm{~cm} / \mathrm{min}$ and a stripping velocity of $6.5 \mathrm{~cm} / \mathrm{min}$.

3 Strip curve for the down-scale column experiment performed at $50^{\circ} \mathrm{C}$ with a loading velocity of $37.7 \mathrm{~cm} / \mathrm{min}$ and a stripping velocity of $6.5 \mathrm{~cm} / \mathrm{min}$.

4 Strip curve for the down-scale column experiment performed at $25^{\circ} \mathrm{C}$ with a loading velocity of $28.2 \mathrm{~cm} / \mathrm{min}$ and a stripping velocity of $6.5 \mathrm{~cm} / \mathrm{min}$

5 Strip curve for the down-scale column experiment performed at $25^{\circ} \mathrm{C}$ with a loading velocity of $32.9 \mathrm{~cm} / \mathrm{min}$ and a stripping velocity of $6.5 \mathrm{~cm} / \mathrm{min}$.

6 Strip curve for the down-scale column experiment performed at $25^{\circ} \mathrm{C}$ with a loading velocity of $37.7 \mathrm{~cm} / \mathrm{min}$ and a stripping velocity of $6.5 \mathrm{~cm} / \mathrm{min}$. 


\section{TABLES}

1 AMORE concentration column design and parameters are shown in the top 3 rows and down-scale AMORE concentration column design and parameters that were

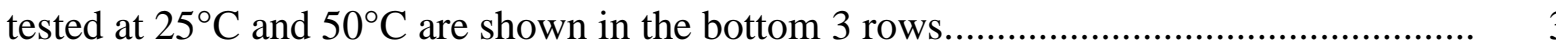

2 Results for the downs-scale concentration column experiments at $50^{\circ} \mathrm{C}$ and $25^{\circ} \mathrm{C} \ldots \ldots \ldots . . .4$ 


\section{DIRECT DOWN-SCALE EXPERIMENTS OF CONCENTRATION COLUMN DESIGNS FOR SHINE PROCESS}

\section{INTRODUCTION}

Argonne is assisting SHINE Medical Technologies in their efforts to become a domestic Mo-99 producer. The SHINE accelerator-driven process uses a uranyl-sulfate target solution for the production of fission-product Mo-99. Argonne has developed a molybdenum recovery and purification process for this target solution. The process includes an initial Mo recovery column followed by a concentration column to reduce the product volume from 15-25 L to $<1 \mathrm{~L}$ prior to entry into the LEU Modified Cintichem (LMC) process for purification. ${ }^{1}$ This report discusses direct down-scale experiments of the plant-scale concentration column design, where the effects of loading velocity and temperature were investigated.

Argonne has collected data from batch studies and breakthrough column experiments to utilize the VERSE (Versatile Reaction Separation) simulation program (Purdue University) to design plant-scale recovery and concentration columns [1,2]. Plant-scale column designs for both the Mo-recovery and Mo-concentration columns were tested and verified in direct down-scale column experiments using non-irradiated and irradiated solutions $[1,3,4]$.

The purpose of this set of experiments was to examine the effects of (1) increased linear velocities on the adsorption of Mo on the concentration column during loading and (2) decreased temperatures on Mo loading and stripping. In the phase-1 AMORE (Argonne Mo Research and development Experiment) experiments, data suggest that more than 15 column volumes (CVs) of strip solution were required to fully strip Mo from the initial Mo-recovery column $[4,5]$. We performed the down-scale concentration column experiments prior to the Mo-99 spike experiments planned for the phase-2 AMORE experiments. The purpose was to ensure that the increased linear velocities required to load potentially larger strip volumes from the initial Morecovery column would not affect Mo adsorption. Additionally, lower temperatures of $25^{\circ} \mathrm{C}$ and $50^{\circ} \mathrm{C}$ compared to the design temperatures of $80^{\circ} \mathrm{C}$ were investigated to determine if Mo adsorption and recoveries would be changed.

1 Although not their primary purpose, the recovery and concentrations columns both act to partially purify the Mo from actinides and other fission products. 


\section{EXPERIMENTAL}

\section{PREPARATION OF MO-99 SPIKE SOLUTION}

Molybdenum-99 was obtained from a Tc-99m generator (provided by Lantheus Medical Imaging). The initial activity of Mo-99 in a generator is $1 \mathrm{Ci}$. Molybdeum-99 was removed from the generator by placing a serum vial containing $1 \mathrm{M} \mathrm{NH} 4 \mathrm{OH}$ on the needle labeled "Saline Charge". Then, an evacuated serum vial was placed on the needle labeled "Receiver". When no more bubbles appeared in the "Receiver" vial, the "Receiver" bottle was removed from the generator. The Mo-99 spiked solution was prepared by bringing the solution to dryness on a hot plate, and re-dissolving it in $0.01 \mathrm{M} \mathrm{HNO}_{3}$.

\section{AKTA COLUMN EXPERIMENTS}

Omnifit columns $(0.66 \mathrm{~cm} \mathrm{~L} \mathrm{x} 1.25 \mathrm{~cm}$ ID) filled with titania sorbent (Sachtopore, $40-\mu \mathrm{m}$ particle size, $60 \AA$ pores) were utilized for the down-scale experiments. The sorbent and column after packing were pre-equilibrated with $0.01 \mathrm{M} \mathrm{HNO}_{3}$. Solutions containing $1.33 \mathrm{ppm}$ Mo (14 $\mu \mathrm{M}$ Mo), 1.14 ppm Mo (12 $\mu \mathrm{M}$ Mo), and 1 ppm Mo (10.4 $\mu \mathrm{M}$ Mo) were spiked with Mo-99 in $1 \mathrm{M} \mathrm{NaNO}_{3}(\mathrm{pH}$ 2) and were used as the feed solutions. Concentrations were based on the Mo concentration expected in the SHINE target solution, assuming 100\% Mo recovery from the initial titania column. These calculations were based on the total volume of strip solution from the recovery column, which becomes the feed for the concentration column.

An AKTA Purifier unit was used to pass the feed solution through the column in the up-flow direction. After the feed solution was loaded, $10 \mathrm{CVs}$ of $0.01 \mathrm{M} \mathrm{HNO}_{3}$ and $10 \mathrm{CVs}$ of $\mathrm{H}_{2} \mathrm{O}$ plus an additional $10 \mathrm{~mL}$ of each solution to make up for the system dead volume were passed through the column in the up-flow direction. Molybdenum was stripped from the column after passing $35 \mathrm{CVs}$ of $1 \mathrm{M} \mathrm{NaOH}$ in addition to $10 \mathrm{~mL}$ to account for the system dead volume in the down-flow direction. A final water wash of $10 \mathrm{CVs}$ plus $10 \mathrm{~mL}$ to account for the system dead volume was passed through the column in the down-flow direction. All solution inlets had been primed and filled to the injection valve to minimize dead volume in the system, but the dead volume was still $10 \mathrm{~mL}$ due to the heating coil prior to column loading and stripping. Column experiments were performed at 25 and $50^{\circ} \mathrm{C}$.

\section{COUNTING OF MO-99}

The amount of activity in the aqueous samples was determined with a $\mathrm{NaI}(\mathrm{Tl})$ well-type detector. Molybdeum-99 was quantified by measurement of its $739 \mathrm{keV} \gamma$-ray. The activity of Mo-99 in each sample was corrected for decay. Errors associated with these results are $\pm 5 \%$. 


\section{RESULTS AND DISCUSSION}

The down-scale concentration column experiments were based on the design for the phase-2 AMORE concentration column $(1.5 \mathrm{~cm}$ ID x $1.25 \mathrm{~cm} \mathrm{~L})$, which was based on the plantscale column design (5 cm ID x $1.5 \mathrm{~cm} \mathrm{~L}$ ) [2]. However, phase-1 AMORE experiments showed that greater than $15 \mathrm{CV}$ s of strip solution from the initial recovery column were required to fully recover Mo; as a result, increased linear velocities needed to be tested for the concentrationcolumn design to account for the larger strip volumes [4]. Table 1 shows the sizes of the phase- 2 AMORE concentration column design and the different loading velocities and flow rates to be tested on a down-scale version of the phase-2 AMORE concentration column. For the linear velocities that were tested, it was assumed that 20, 24, and $28 \mathrm{CVs}$ of strip solution were required to fully strip Mo from the first recovery column, plus an additional $500 \mathrm{~mL}$ of strip solution to account for the dead volume in the AMORE system, mainly attributed to the transfer line from the glovebox to the BigFoot hot cell. The amount of strip solution needed to fully recover Mo from the initial Mo-recovery column in the AMORE system will be verified during the upcoming Mo-99 spike tests. Slightly increased stripping velocities were tested in the downscale concentration column experiments $(6.5 \mathrm{~cm} / \mathrm{min}$ compared to $5 \mathrm{~cm} / \mathrm{min})$ because the stripping velocity used for the initial recovery column is $6.5 \mathrm{~cm} / \mathrm{min}$, which has been found to work well.

TABLE 1 AMORE concentration column design and parameters are shown in the top 3 rows and down-scale AMORE concentration column design and parameters that were tested at $25^{\circ} \mathrm{C}$ and $50^{\circ} \mathrm{C}$ are shown in the bottom 3 rows.

\begin{tabular}{ccccccc}
\hline & $\begin{array}{c}\text { Feed } \\
\text { Column Size } \\
\text { Volume } \\
(\mathrm{mL})\end{array}$ & $\begin{array}{c}\text { Mo Conc. }(\mathrm{cm}) \\
(\mu \mathrm{M})\end{array}$ & $\begin{array}{c}\text { Loading } \\
\text { Velocity } \\
(\mathrm{cm} / \mathrm{min})\end{array}$ & $\begin{array}{c}\text { Loading } \\
\text { Flow Rate } \\
(\mathrm{mL} / \mathrm{min})\end{array}$ & $\begin{array}{c}\text { Stripping } \\
\text { Velocity } \\
(\mathrm{cm} / \mathrm{min})\end{array}$ & $\begin{array}{c}\text { Stripping } \\
\text { Flow Rate } \\
(\mathrm{mL} / \mathrm{min})\end{array}$ \\
\hline & & & & & & \\
$1.5 \times 1.25$ & 3000 & 14 & 28.2 & 50.0 & 5 & 8.9 \\
$1.5 \times 1.25$ & 3500 & 12 & 32.9 & 58.3 & 5 & 8.9 \\
$1.5 \times 1.25$ & 4000 & 10.4 & 37.7 & 66.7 & 5 & 8.9 \\
& & & & & & \\
$0.66 \times 1.25$ & 575 & 14 & 28.2 & 9.6 & 6.5 & 2.2 \\
$0.66 \times 1.25$ & 671 & 12 & 32.9 & 11.2 & 6.5 & 2.2 \\
$0.66 \times 1.25$ & 769 & 10.4 & 37.7 & 12.8 & 6.5 & 2.2 \\
\hline
\end{tabular}

Table 2 shows the results for the down-scale concentration column tests $(0.66 \mathrm{~cm} \mathrm{x}$ $1.25 \mathrm{~cm})$. Column effluents \#1 and \#2 represent the first and second half of feed solution loaded onto the column, respectively. Results indicate better adsorption at $50^{\circ} \mathrm{C}$ versus $25^{\circ} \mathrm{C}$, with the exception of the $37.7 \mathrm{~cm} / \mathrm{min}$ loading experiment performed at $25^{\circ} \mathrm{C}$. For the $50^{\circ} \mathrm{C}$ experiments, the average Mo found in the column effluent was $0.18 \%$, and the loading velocity had no effect on Mo adsorption. For the $25^{\circ} \mathrm{C}$ experiments, the average Mo found in the effluent was $0.67 \%$, and again, the loading velocity appeared to have no effect on Mo adsorption. Because diffusion into the pores was better at higher temperatures, we recommend that loading be done between 
TABLE 2 Results for the downs-scale concentration column experiments at $50^{\circ} \mathrm{C}$ and $25^{\circ} \mathrm{C}$.

\begin{tabular}{|c|c|c|c|c|c|c|c|c|}
\hline $\begin{array}{l}\text { Loading } \\
\text { Velocity } \\
(\mathrm{cm} / \mathrm{min})\end{array}$ & $\begin{array}{r}\text { Stripping } \\
\text { Velocity } \\
(\mathrm{cm} / \mathrm{min}) \\
\end{array}$ & $\begin{array}{c}\text { Temperature } \\
\left({ }^{\circ} \mathrm{C}\right)\end{array}$ & $\begin{array}{c}\% \text { Mo in } \\
\text { Column } \\
\text { Effluent \#1 }\end{array}$ & $\begin{array}{c}\% \text { Mo in } \\
\text { Column } \\
\text { Effluent \#2 }\end{array}$ & $\begin{array}{c}\text { \% Mo in } \\
\text { Acid } \\
\text { Wash }\end{array}$ & $\begin{array}{c}\% \text { Mo in } \\
1 \text { st Water } \\
\text { Wash }\end{array}$ & $\begin{array}{l}\% \text { Mo } \\
\text { in Strip }\end{array}$ & $\begin{array}{c}\% \text { Mo in } \\
\text { 2nd Water } \\
\text { Wash }\end{array}$ \\
\hline 28.2 & 6.5 & 50 & 0.2 & 0.02 & 0.003 & 0.003 & 96.2 & 0.1 \\
\hline 32.9 & 6.5 & 50 & 0.1 & 0.07 & 0.004 & 0.004 & 100 & 0.2 \\
\hline 37.7 & 6.5 & 50 & 0.1 & 0.06 & 0.005 & 0.004 & 93.1 & 0.1 \\
\hline 28.2 & 6.5 & 25 & 0.2 & 0.3 & 0.03 & 0.002 & 86.2 & 0.2 \\
\hline 32.9 & 6.5 & 25 & 0.8 & 0.5 & 0.002 & 0.03 & 91.7 & 0.3 \\
\hline 37.7 & 6.5 & 25 & 0.1 & 0.1 & 0.005 & 0.003 & 86.1 & 0.5 \\
\hline
\end{tabular}

50 and $80^{\circ} \mathrm{C}$. Results also indicate that better Mo recovery is achieved at $50^{\circ} \mathrm{C}$ compared to $25^{\circ} \mathrm{C}$, where the average Mo recovered was $96.4 \%$ at $50^{\circ} \mathrm{C}$ and $88 \%$ at $25^{\circ} \mathrm{C}$. Again, this is due to better diffusion of the $1 \mathrm{M} \mathrm{NaOH}$ into the sorbent pores to release the Mo. We thus recommend that stripping be done between 50 and $80^{\circ} \mathrm{C}$.

Stripping curves for the conditions in Table 2 are shown in Figures 1-6. The results in Figures 4-6 $\left(25^{\circ} \mathrm{C}\right.$ experiments) indicate that the majority of Mo is recovered in a $5 \mathrm{~mL}$ fraction of $1 \mathrm{M} \mathrm{NaOH}$, which is equivalent to $11.6 \mathrm{CVs}$. There is little to no activity observed in the first $10 \mathrm{~mL}$, which is equivalent to the dead volume in the system. Not enough fractions of strip solution were collected for the $50^{\circ} \mathrm{C}$ experiments (Figures 1-3) to show that most of the Mo is collected in a $5 \mathrm{~mL}$ fraction rather than a $10 \mathrm{~mL}$ fraction, but this is evident in the $25^{\circ} \mathrm{C}$ experiments, where smaller fractions were taken after $10 \mathrm{~mL}$ of solution was passed through the column representing the system dead volume. Figures 4-6 suggest that $5 \mathrm{~mL}$ of solution in addition to the system dead volume is required to fully recover the Mo. For phase-2 AMORE and plant-scale concentration column experiments, we recommend that the volume of solution representing the system dead volume be discarded, and 12-15 CVs of $1 \mathrm{M} \mathrm{NaOH}$ be used to strip the Mo from the concentration column. 


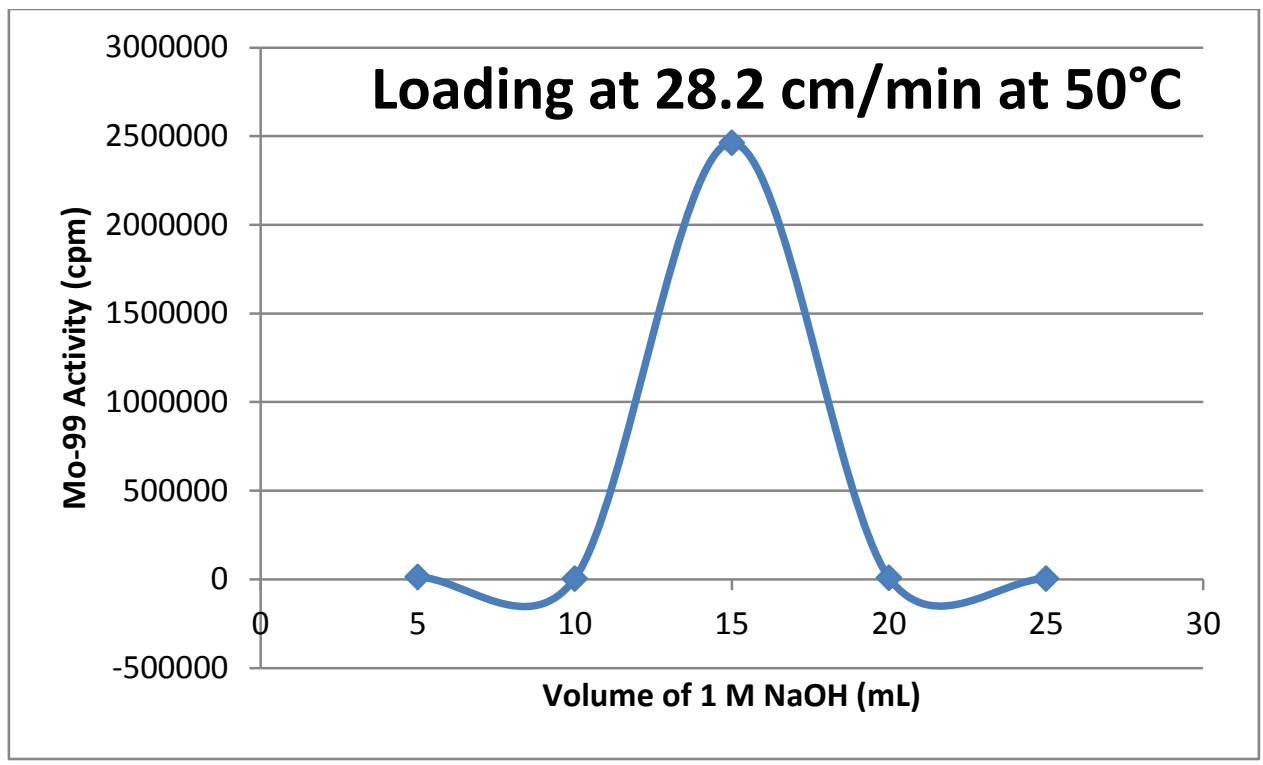

FIGURE 1 Strip curve for the down-scale column experiment performed at $50^{\circ} \mathrm{C}$ with a loading velocity of $28.2 \mathrm{~cm} / \mathrm{min}$ and a stripping velocity of $6.5 \mathrm{~cm} / \mathrm{min}$.

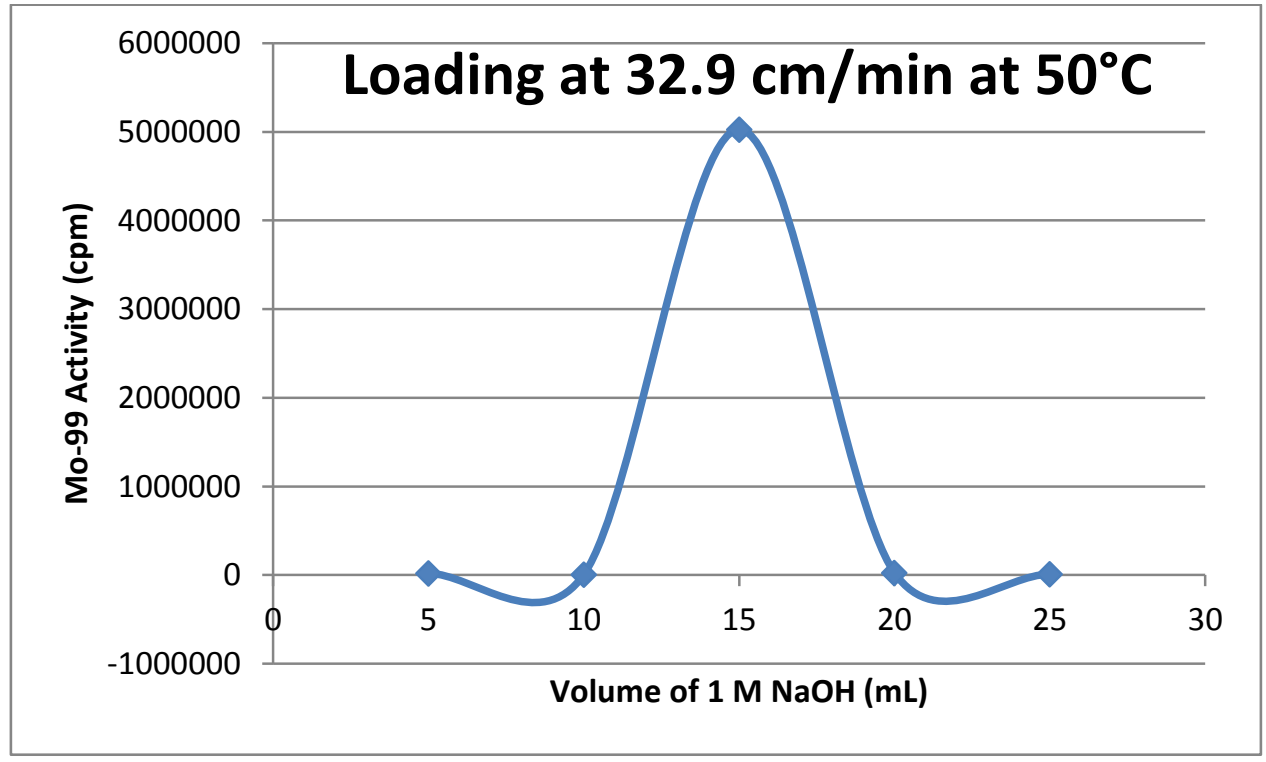

FIGURE 2 Strip curve for the down-scale column experiment performed at $50^{\circ} \mathrm{C}$ with a loading velocity of $32.9 \mathrm{~cm} / \mathrm{min}$ and a stripping velocity of $6.5 \mathrm{~cm} / \mathrm{min}$. 


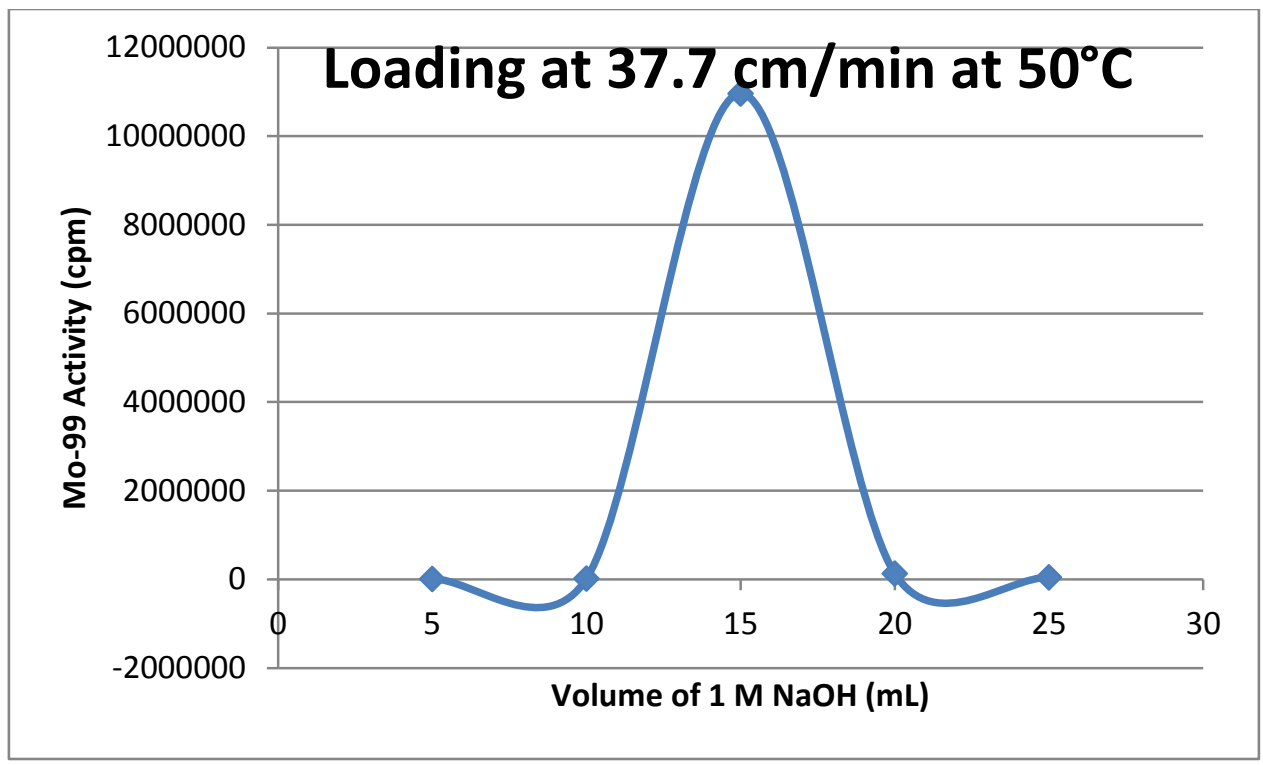

FIGURE 3 Strip curve for the down-scale column experiment performed at $50^{\circ} \mathrm{C}$ with a loading velocity of $37.7 \mathrm{~cm} / \mathrm{min}$ and a stripping velocity of $6.5 \mathrm{~cm} / \mathrm{min}$.

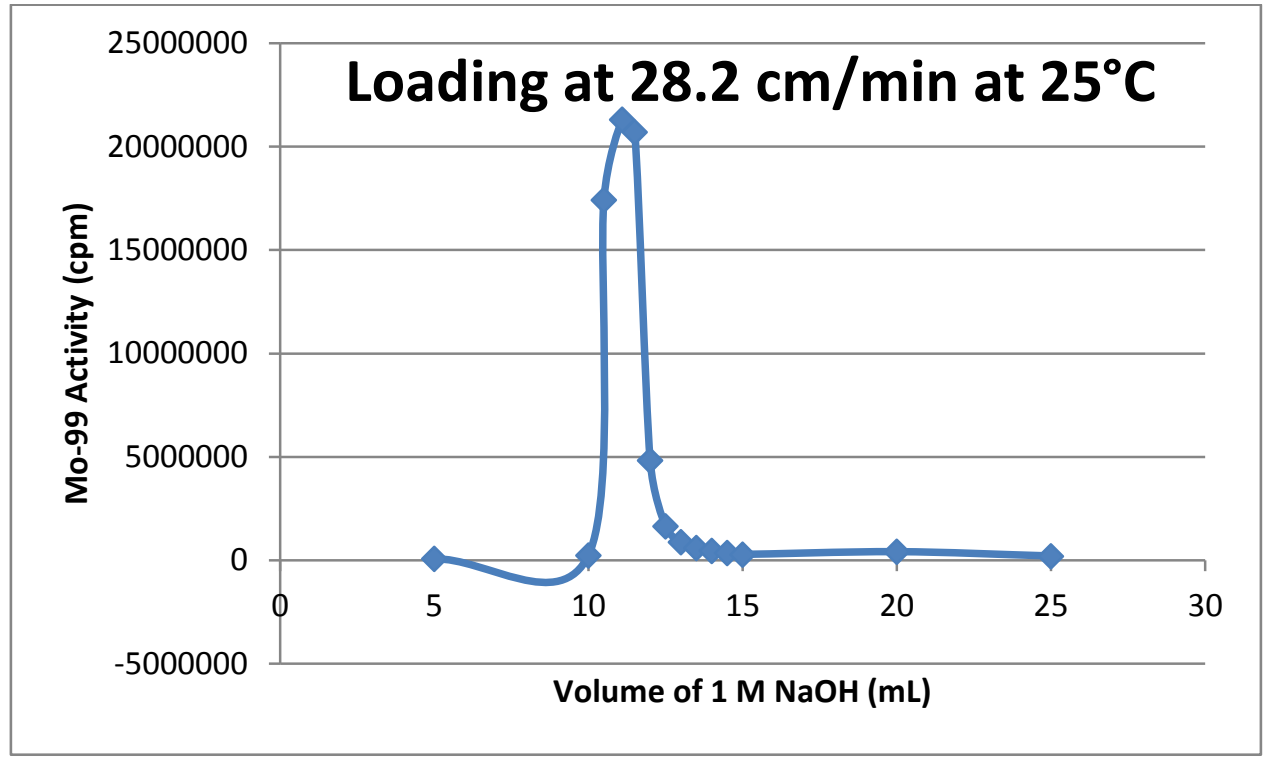

FIGURE 4 Strip curve for the down-scale column experiment performed at $25^{\circ} \mathrm{C}$ with a loading velocity of $28.2 \mathrm{~cm} / \mathrm{min}$ and a stripping velocity of $6.5 \mathrm{~cm} / \mathrm{min}$. 


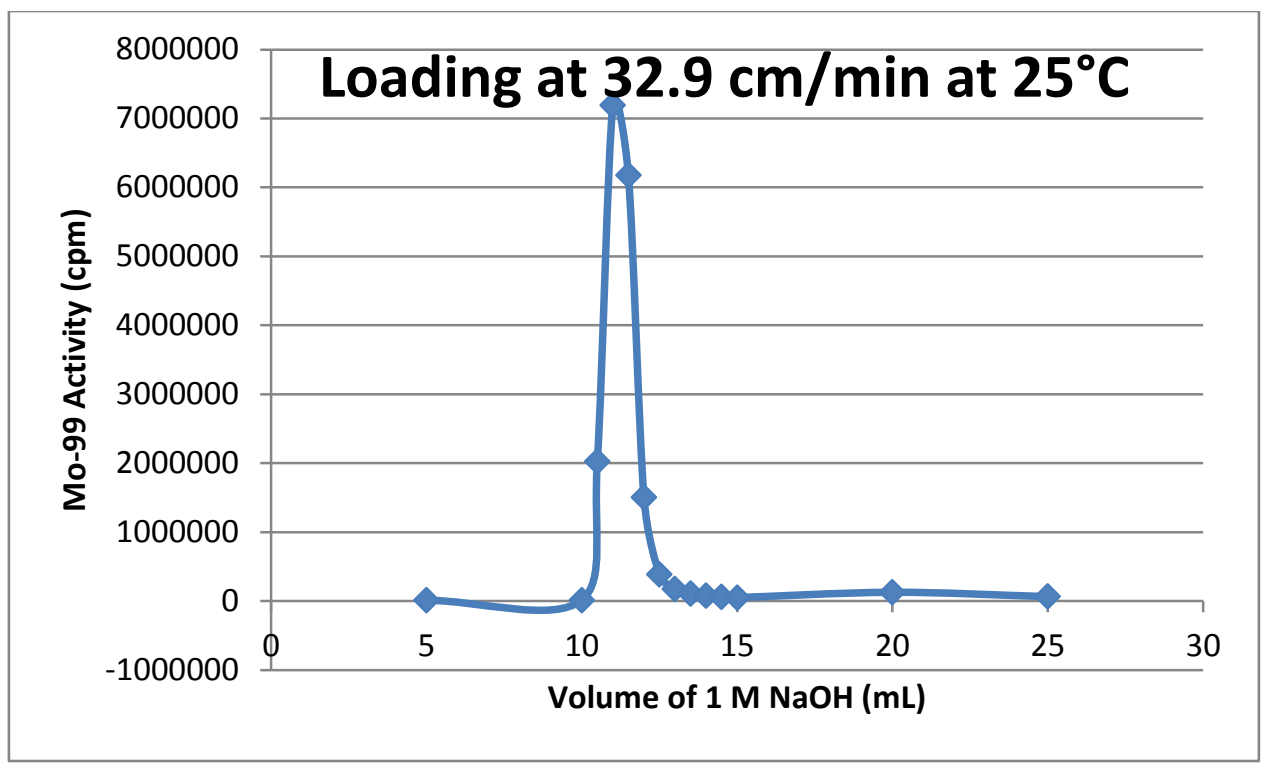

FIGURE 5 Strip curve for the down-scale column experiment performed at $25^{\circ} \mathrm{C}$ with a loading velocity of $32.9 \mathrm{~cm} / \mathrm{min}$ and a stripping velocity of $6.5 \mathrm{~cm} / \mathrm{min}$.

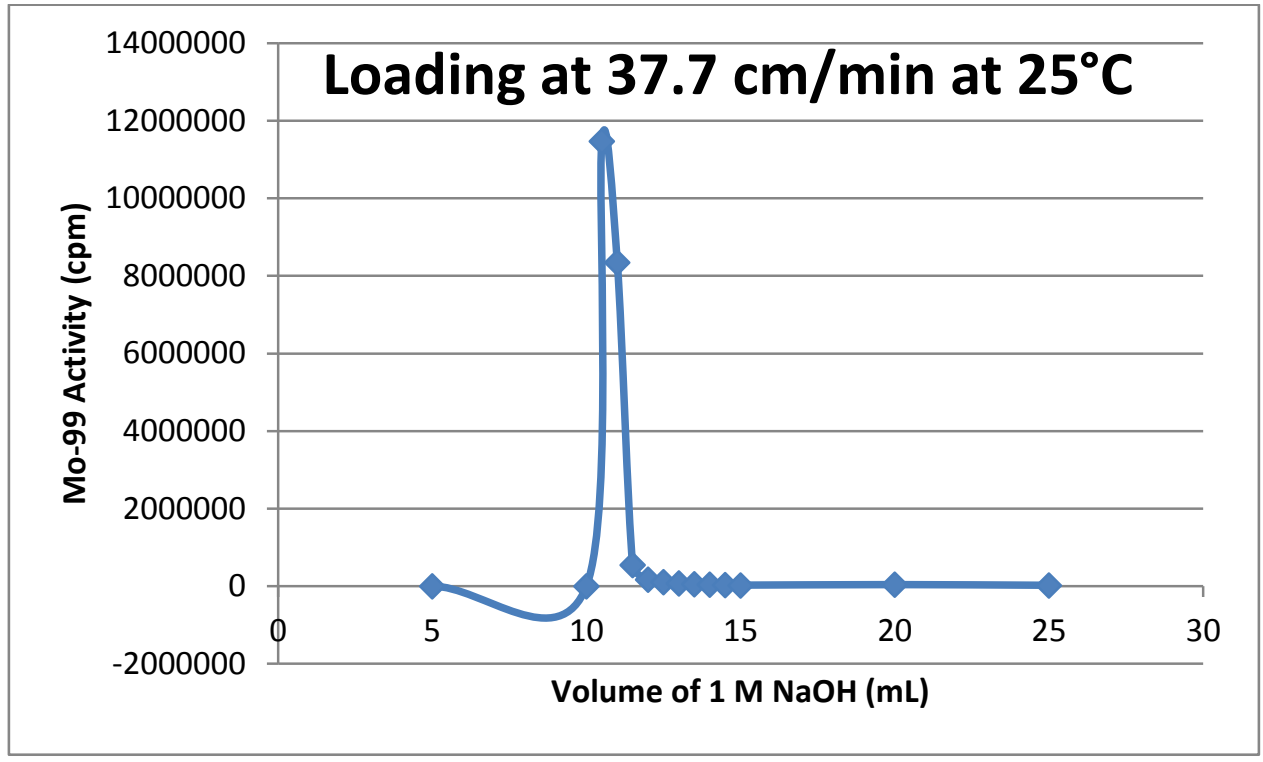

FIGURE 6 Strip curve for the down-scale column experiment performed at $25^{\circ} \mathrm{C}$ with a loading velocity of $37.7 \mathrm{~cm} / \mathrm{min}$ and a stripping velocity of $6.5 \mathrm{~cm} / \mathrm{min}$. 


\section{CONCLUSIONS}

We are recommending that the concentration column steps be performed at a temperature between 50 and $80^{\circ} \mathrm{C}$ for optimum adsorption and recovery of Mo. There appears to be no effect of loading linear velocity between 28.2 and $37.7 \mathrm{~cm} / \mathrm{min}$ for Mo adsorption, so use of a larger volume of strip solution from the initial recovery column should not be an issue. Additionally, we found that the majority of the Mo was recovered in a $5 \mathrm{~mL}(11.6 \mathrm{CV})$ fraction after the amount of solution representing the system dead volume was passed through the column. To be conservative, we recommend that Mo be stripped from the concentration column with 12-15 CVs of $1 \mathrm{M} \mathrm{NaOH}$, in addition to the system dead volume, which can be discarded. This will help minimize the volume of solution entering the LMC process for the plant-scale process. The LMC process cannot handle volumes larger than $\sim 125-150 \mathrm{~mL}$ with the glassware that is currently used, so either new glassware will be needed or an evaporation step must be added to the process. The current plant-scale concentration column design is a $5 \mathrm{~cm} \mathrm{ID} \mathrm{x} 1.25 \mathrm{~cm} \mathrm{~L} \mathrm{column,}$ which has a column volume of $25 \mathrm{~mL}$. If $12-15 \mathrm{CVs}$ of strip solution were required to fully recover the Mo, 300-375 mL solution would need to be reduced to $125-150 \mathrm{~mL}$ or an evaporation step would be needed to bring the volume of solution to $125-150 \mathrm{~mL}$. 


\section{REFERENCES}

[1] Youker, A.J., Stepinski, D.C., Ling, L., Chung, P.-L., and Vandegrift, G.F., Plant-Scale Column Designs for SHINE Target Solutions, ANL/CSE-14/24 (June 29, 2012).

[2] Stepinski, D.C., Youker, A.J., and Vandegrift, G.F., Plant-Scale Concentration Column Designs for SHINE Target Solution, ANL/CSE-13/24 (September 28, 2012).

[3] Stepinski, D.C., Krebs, J.F., Youker, M.J., Hebden, A.S., and Vandegrift, G.F., Documenting Dual-Column Experiment with Mini-SHINE Solution, ANL/CSE-13/46 (September 30, 2013).

[4] Vandegrift, G.F., et al., Compendium of Phase-I Mini-SHINE Experiments, ANL/NE-16/39 (September 19, 2016).

[5] Youker, A.J., Chemerisov, S.D., Tkac, P., Kalensky, M., Heltemes, T.A., Rotsch, D.A. Vandegrift, G.F., Krebs, J.F., Makarashvili, V., Stepinski, D.C., "Fission Produced ${ }^{99}$ Mo without a Nuclear Reactor," Journal of Nuclear Medicine, 116, 181040 (2016). 
This page intentionally left blank 



\section{Argonne}

Nuclear Engineering Division

Argonne National Laboratory

9700 South Cass Avenue, Bldg. 208

Argonne, IL 60439-4854

www.anl.gov

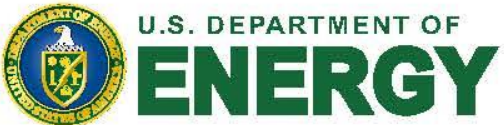

Argonne National Laboratory is a U.S. Department of Energy laboratory managed by UChicago Argonne, LLC 